\title{
OPTICAL INVESTIGATION OF CATION DEFECTS IN IRRADIATED $\mathrm{RbBr}$
}

\author{
(Presented by Ch. Lushchik)
}

An $X$-ray or UV irradiation of $\mathrm{RbBr}$ crystals at 80 and $190 \mathrm{~K}$ creates $\mathrm{Br}_{3}^{-}$centers oriented along $\langle 100\rangle$ directions. The photodissociation of these centers creates $V_{F}$ centers. $X$-irradiation also brings about an absorption band at $5.4 \mathrm{eV}$, stable up to $425 \mathrm{~K}$, which can be interpreted as the absorption of interstitial dipoles $\mathrm{Rb}_{i}+\mathrm{Br}_{i}{ }^{-}$.

\section{Introduction}

Basic data on radiation defects in alkali halides have been obtained for $\mathrm{KCl}$ and $\mathrm{KBr}$ crystals $\left[{ }^{1,2}\right]$. In these crystals $X$-irradiation at $4.2 \mathrm{~K}$ creates pairs of anion Frenkel defects: either the anion vacancies $v_{a}^{+}$ ( $\alpha$ centers) and interstitial halogen ions $i_{a}^{-}$( $I$ centers), or $F$ and $H$ centers $\left(v_{a}{ }^{+} e^{-}\right.$and $\left.i_{a}{ }^{0}\right)$. Recently it has also been shown that in some alkali halides $X$-irradiation creates pairs of cation Frenkel defects: the cation vacancies $v_{c}^{-}$and interstitial cations $i_{c}{ }^{+}$as well as complex associations of defects with cation vacancies and holes as their components - $V_{F}$ centers $\left(v_{c}-e^{+}\right)$and $V_{4}$ centers $\left.\left(v_{c}-e^{+} i_{a}{ }^{0}\right){ }^{[3-7}\right]$.

The aim of the present study is to investigate optically cation defects in $\mathrm{RbBr}$ which become apparent in the $X$-irradiation-induced absorption and optical dichroism spectra and thermally stimulated luminescence (TSL).

In $\left[{ }^{8}\right]$ the absorption spectra of $\mathrm{RbBr} X$-rayed at $16 \mathrm{~K}$ were investigated, and the absorption bands of $I$ centers $(5.45$ and $5.20 \mathrm{eV}), H$ centers $(3.25 \mathrm{eV})$ and a broad band with the maximum at $4.18 \mathrm{eV}$ were detected. The intensity of the latter is proportional to the square of the $H$-band intensity and, according to $\left[{ }^{8}\right]$, it is associated with di- $H$-centers. The annealing of $I$ centers in the region of 40 to $60 \mathrm{~K}$ was studied in $\left[{ }^{9}\right]$. The $V_{K}$ centers in $\mathrm{RbBr}$ are described in $\left[{ }^{10}\right]$. Cation Frenkel defects in $\mathrm{RbBr}$ have not practically been studied.

In the absorption spectrum of $\mathrm{RbBr}$ at $80 \mathrm{~K}$ the bands at 6.6 and $\pi .08 \mathrm{eV}$ correspond to the $e^{0}$ excitons.

\section{Experimental}

The crystals of $\mathrm{RbBr}$ were grown by the method of sixty-fold recrystallization at the Institute of Physics of the Academy of Sciences of the Estonian SSR $\left[{ }^{11}\right]$. The investigation of ionic conductivity showed that the transition to the intrinsic conductivity occurs at $290^{\circ} \mathrm{C}$, which testifies to the high purity of the crystals relative to divalent metals $\left(\mathrm{C}\left(\mathrm{Me}^{2+}\right) \leqslant\right.$ $\left.\leqslant 10^{-2} \mathrm{ppm}\right)$. $\mathrm{RbBr}$ platelets of approximately $10 \times 10 \times 1.5 \mathrm{~mm}^{3}$ freshly cleaved along the $\{100\}$ planes were studied. The crystal was placed into 
a cryostat with a sorption pump and was $X$-irradiated through a beryllium window using a tube with a tungstem target operating at $60 \mathrm{kV}$ and $15 \mathrm{~mA}$. The exposure time $(5 \mathrm{~h})$ corresponds to the absorbed dose of 50 Mrd.

The absorption spectra were recorded at $80 \mathrm{~K}$ before and after the irradiation on a "Specord UV VIS» spectrophotometer. In the figures, the spectra of the absorption induced by $X$-irradiation are shown. To determine the orientation of color centers, the $X$-rayed crystals were hleached by linearly polarized light and subsequently the optically induced linear dichroism was investigated according to $\left[{ }^{12-14}\right]$. The polarization degree of the light obtained by using polaroids, was about 100 per cent in the region of 3.5 to $5.1 \mathrm{eV}$. The bleaching was performed with the light from an SVD-120A Hg discharge lamp or a powerful DDS-400 deuterium lamp through an MDR-23 monochromator. The integral TSL in the region of 80 to $450 \mathrm{~K}$ was recorded mostly at the heating rate $\beta=0.15 \mathrm{~K} / \mathrm{s}$, in the region of 4.2 to $80 \mathrm{~K}-\beta=0.015 \mathrm{~K} / \mathrm{s}$.

\section{Experimental results}

The absorption spectra of $\mathrm{RbBr}$ induced by $X$-irradiation at 80,190 , and $300 \mathrm{~K}$, are shown in Fig. 1. In the spectra an intensive $F$ band $(1.81 \mathrm{eV})$, an $\alpha$ band $(6.02 \mathrm{eV})$, and a $\beta$ band $(6.31 \mathrm{eV})$ can be seen. The absorption band in the region of 5.8 to $5.0 \mathrm{eV}$ typical of $I$ centers, in the region of 5.0 to $3.7 \mathrm{eV}$ typical of $V_{2}$ and $V_{4}$ centers, and in the region of 3.6 to $2.7 \mathrm{eV}$ typical of $V_{K}, V_{F}$, and $H$ centers are observable. The broad absorption bands in the regions of 5.8 to $5.0 \mathrm{eV}$ and of 5.0 to $3.7 \mathrm{eV}$ (half-width $\delta>1 \mathrm{eV}$ ) are non-elementary. To divide them into elementary components the pulse annealing of $X$-rayed crystals was used: the crystal was heated up to definite temperatures (exposure

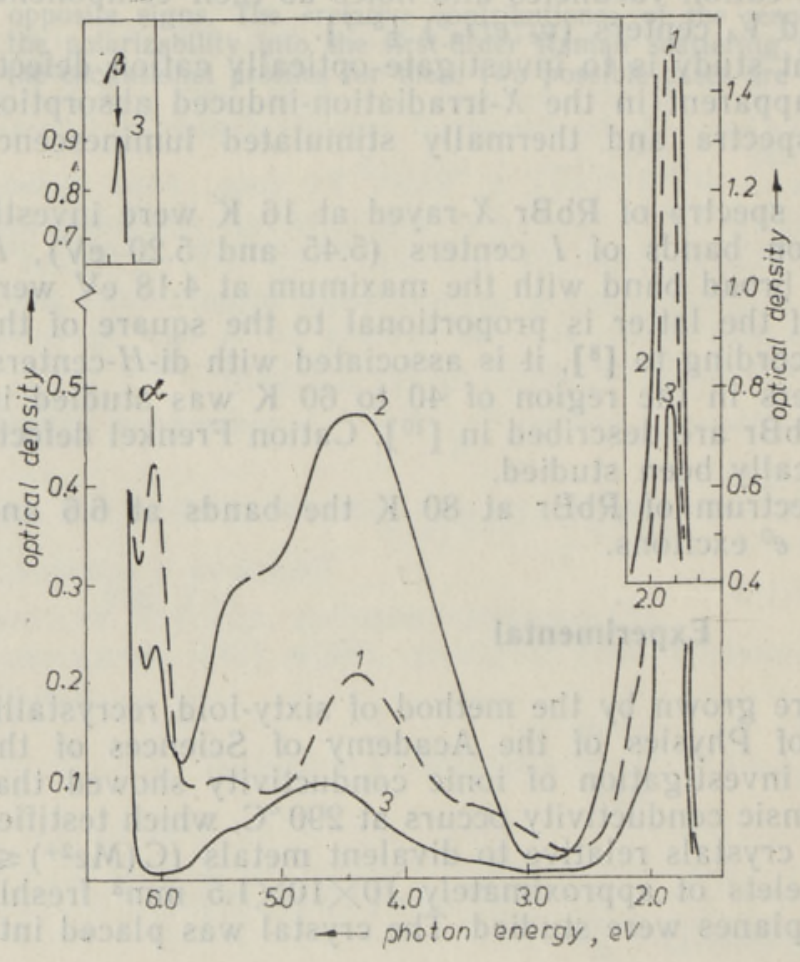

Fig. 1. Absorption spectra of $\mathrm{RbBr} X$-irradiated at $80(1)$, $190(2)$, and $300 \mathrm{~K}(3)$. 


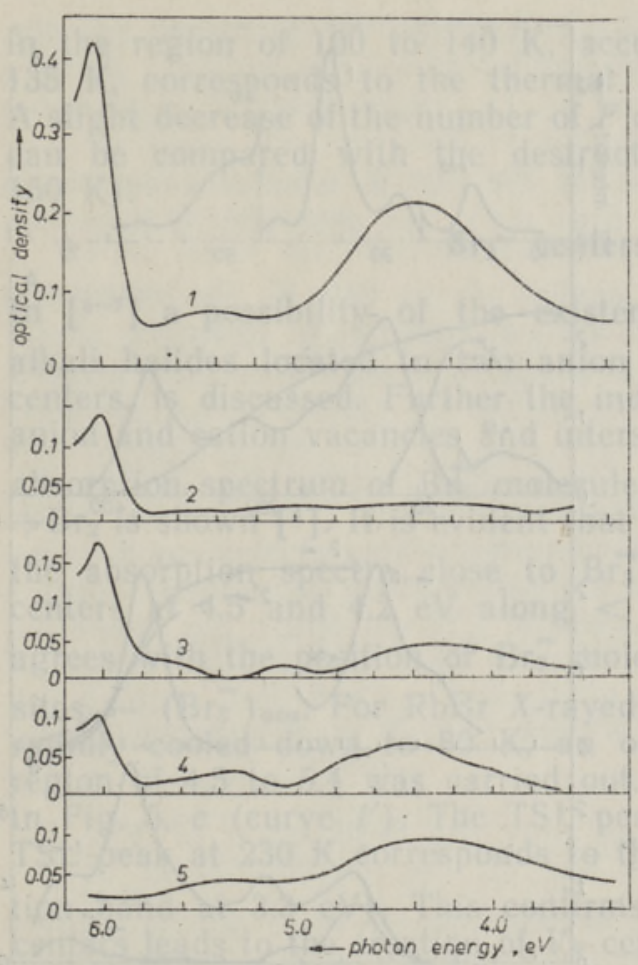

Fig. 2. Absorption spectrum of $\mathrm{RbBr}$ after an $X$-irradiation at $80 \mathrm{~K}(1)$ and the decrease of the absorption after heating from 80 to $170 \mathrm{~K}$ (2), from 170 to $240 \mathrm{~K}(3)$, from 240 to $300 \mathrm{~K}$ (4), and from 300 to $400 \mathrm{~K}(5)$.

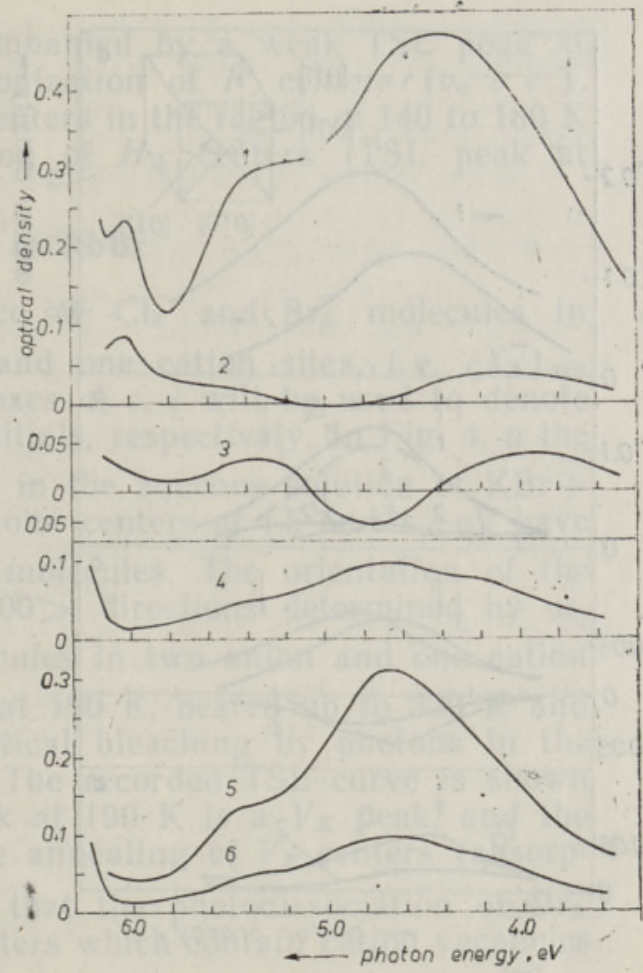

Fig. 3. Absorption spectrum of $\mathrm{RbBr} X$ irradiated at $190 \mathrm{~K}(1)$ and the decrease of the absorption after heating from 240 to $280 \mathrm{~K}(2)$, from 280 to $320 \mathrm{~K}$ (3), from 320 to $360 \mathrm{~K}$ (4), from 360 to $400 \mathrm{~K}(5)$, and from 400 to $425 \mathrm{~K}(6)$.

2 min), rapidly cooled down to $80 \mathrm{~K}$, and then the absorption spectra were measured.

The absorption spectra of $\mathrm{RbBr}$ crystals $X$-rayed at 80 or $190 \mathrm{~K}$ and annealed in the definite temperature region, are shown in Figs. 2 and 3. An analysis of the data presented in these figures shows that in the region of 5.8 to $5.0 \mathrm{eV}$ low-temperature (annealed up to $240 \mathrm{~K}$ ) and high-temperature (annealed up to $425 \mathrm{~K}$ ) $I$ centers can be distinguished. In the region of 5.0 to $3.7 \mathrm{eV}$ for the crystals $X$-rayed at $80 \mathrm{~K}$, it is possible to single out the centers with the absorption maxima at 4.2 and $4.5 \mathrm{eV}$ and for the crystals $X$-rayed at $190 \mathrm{~K}$, the absorption bands at $4.2,4.5$, and $4.8 \mathrm{eV}$.

For a more detailed analysis of 5.0 to $3.7 \mathrm{eV}$ region, a selective bleaching of crystals by 4.68 or $3.97 \mathrm{eV}$ photons (propagation vector parallel to [100]) was performed. After bleaching $\mathrm{RbBr}$ with light, the electric vector being parallel to [001] (subsequently the term «[001] light» will be used), the absorption measured with [001] light decreases, and the absorption measured with [010] light slightly increases (see Fig. $4, c)$. The optical dichroism along the $C_{4}$ axis was determined as the difference of absorption coefficients $D_{4}=K_{010}-K_{001}$ (see Fig. $4, b, d$ ). Analogously, after the bleaching with [011] light, the absorption spectra with [011] and [011] lights were measured. Dichroism along the axis $C_{2}$ was determined as $D_{2}=K_{011}-K_{011}$ (see Fig. $\left.4, b, d\right)$. 


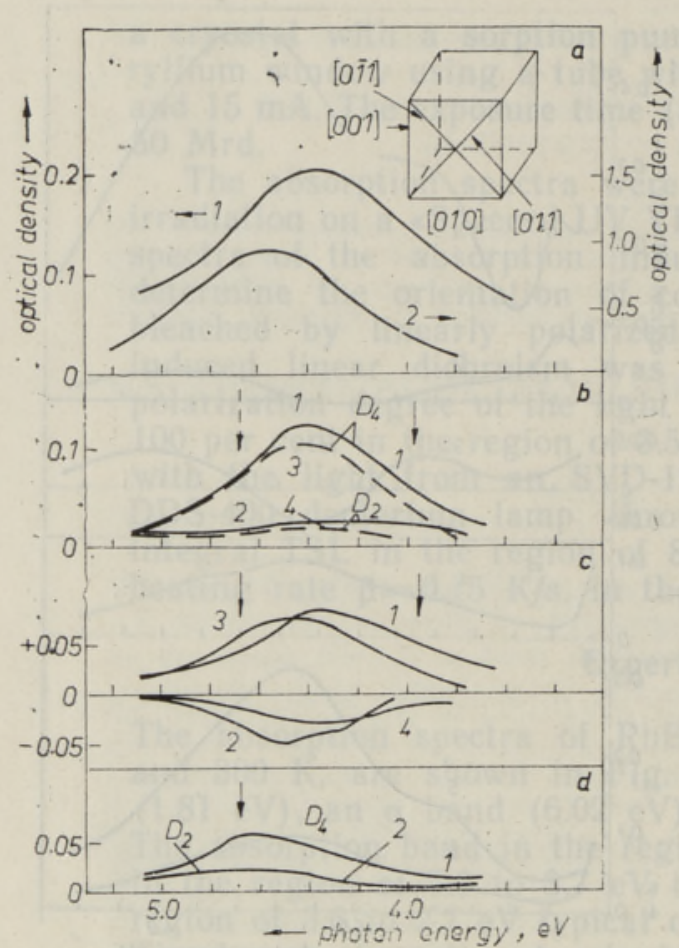

Fig. 4. Optical spectra of a $\mathrm{RbBr}$ crystal. $a$ - Absorption spectra of $\mathrm{Br}_{3}-$ molecules in $\mathrm{RbBr} X$-irradiated at $80 \mathrm{~K}(1)$ and in an aqueous solution at $300 \mathrm{~K}(2), b-$ Optical dichroism induced by bleaching with [001] $(1,3)$ and [011] light $(2,4)$ in $\mathrm{RbBr} X$-irradiated at $80 \mathrm{~K}$. Energy of photons is $3.97 \mathrm{eV}(1,2)$ and $4.68 \mathrm{eV}(3$, 4). c - Decrease of [001] light absorption $(1,3)$ and increase of [010] light absorption $(2,4)$ in $\mathrm{RbBr} X$-irradiated at $80 \mathrm{~K}$ after bleaching with [001] light, Energy of the photons is $3.97 \mathrm{eV}(1,2)$ and $4.68 \mathrm{eV}(3,4) . d$ - Optical dichroism induced by bleaching with [001] (I) and [011] (2) light (4.68 eV photons) in $\mathrm{RbBr}$ $X$-irradiated at $190 \mathrm{~K}$.

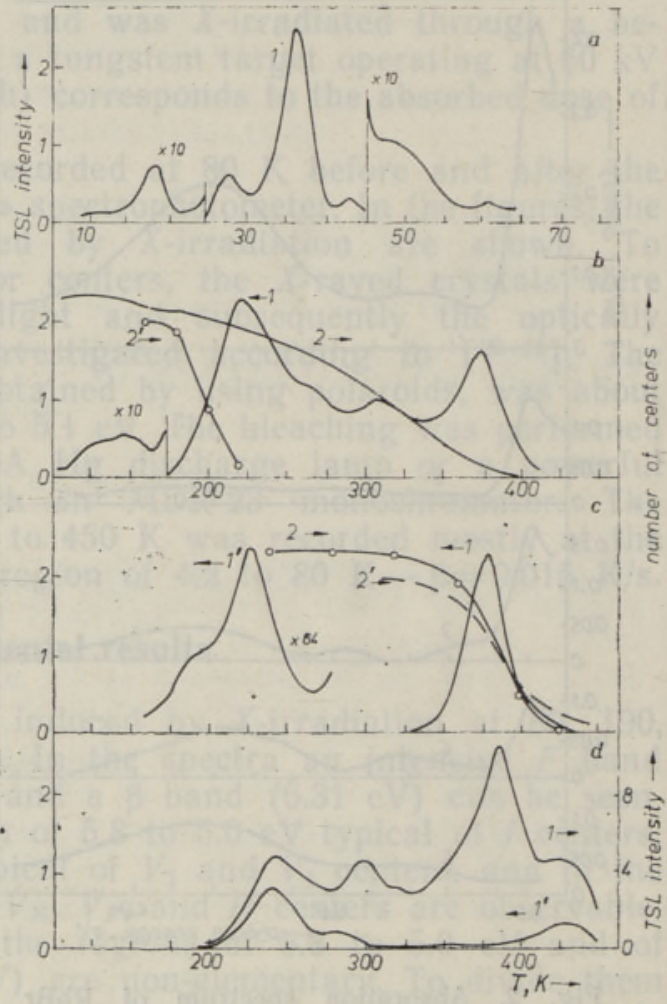

Fig. 5. Integral intensity of thermally stimulated luminescence $\left(1,1^{\prime}\right)$ and thermal bleaching of color centers $\left(2,2^{\prime}\right)$ for $\mathrm{RbBr}$ after an $X$-irradiation at $4.2(a), 80(b), 190 \mathrm{~K}(c)$ and after an illumination at $190 \mathrm{~K}(d$, ratio of doses $1: 130$ ) with heating rates $0.015 \mathrm{~K} / \mathrm{s}(a), 0.15 \mathrm{~K} / \mathrm{s}(b, c)$ and $0.3 \mathrm{~K} / \mathrm{s}(d)$. Thermal bleaching of $F$ band at $1.81 \mathrm{eV}(2 b, 2 c)$, of EPR signal of $V_{K}$ center $\left(2^{\prime} b\right)$ and of absorption band at $5.37 \mathrm{eV}\left(2^{\prime} c\right)$.

Linear oscillators are oriented along $C_{4}$ axis (i.e. along $\langle 100\rangle$ directions) if the dichroism $D_{4}$ is present and $D_{2}$ is absent $\left.{ }^{[12}\right]$. It is this case that takes place for color centers with the absorption maxima at 4.2 and $4.5 \mathrm{eV}$. In the region of 4.8 to $5.1 \mathrm{eV}$ very weak dichroism $D_{4}$ and $D_{2}$ can be observed (see Fig. 4, d), which may direct the orientation of color centers at $4.8 \mathrm{eV}$ along $\langle 110\rangle$ directions.

In Fig. 5 the TSL curves of $\mathrm{RbBr}$ crystals $X$-rayed at $4.2,80$, and $190 \mathrm{~K}$ are presented. The curves of the thermal bleaching of $F$ centers $\left(\boldsymbol{\varkappa}_{F}^{m} \cdot T^{1 / 2}\right.$ is taken as the number of $F$ centers $)$, and the centers with the absorption at $5.37 \mathrm{eV}$ measured in the regime of continuous heating, are given as well. The data on the pulse annealing of $F$ centers and the electron paramagnetic resonance (EPR) signal of $V_{K}$ centers are presented in Fig. 5 (curves $2 c$ and $2^{\prime} b$ ). The increase of the number of $F$ centers 
in the region of 100 to $140 \mathrm{~K}$, accompanied by a weak TSL peak at $135 \mathrm{~K}$, corresponds to the thermal ionization of $F^{\prime}$ centers $\left(v_{a}^{+} e^{-} e^{-}\right)$. A slight decrease of the number of $F$ centers in the region of 140 to $180 \mathrm{~K}$ can be compared with the destruction of $H_{A}$ centers (TSL peak at $150 \mathrm{~K})$.

\section{$\mathrm{Br}_{3}-$ centers in $\mathrm{RbBr}$}

In $\left.{ }^{4-7}\right]$ a possibility of the existence of $\mathrm{Cl}_{3}^{-}$and $\mathrm{Br}_{3}^{-}$molecules in alkali halides located in two anion and one cation sites, i. e. $\left(X_{3}^{-}\right)_{\text {aca }}$ centers, is discussed. Further the indexes $a, c, i$ will be used to denote anion and cation vacancies and interstitials, respectively. In Fig. 4, $a$ the absorption spectrum of $\mathrm{Br}_{3}^{-}$molecules in the aqueous solution of $\mathrm{KBr}+$ $+\mathrm{Br}_{2}$ is shown [ ${ }^{4}$ ]. It is evident that color centers of 4.5 and $4.2 \mathrm{eV}$ have the absorption spectra close to $\overrightarrow{\mathrm{Br}_{3}}$ molecules. The orientation of the centers at 4.5 and $4.2 \mathrm{eV}$ along $\langle 100\rangle$ directions determined by us, agrees with the position of $\mathrm{Br}_{3}^{-}$molecules in two anion and one cation sites - $\left(\mathrm{Br}_{3}^{-}\right)_{a c a}$. For $\mathrm{RbBr} X$-rayed at $190 \mathrm{~K}$, heated up to $320 \mathrm{~K}$ and rapidly cooled down to $80 \mathrm{~K}$, an optical bleaching by photons in the region of 4.5 to 5.4 was carried out. The recorded TSL curve is shown in Fig. 5, $c$ (curve $1^{\prime}$ ). The TSL peak at $190 \mathrm{~K}$ is a $V_{K}$ peak, and the TSL peak at $230 \mathrm{~K}$ corresponds to the annealing of $V_{F}$ centers (absorption band at $3.3 \mathrm{eV}$ ). This confirms that the photodissociation of $\mathrm{Br}_{3}$ centers leads to the creation of $V_{F}$ centers which contain cation vacancies $\left[{ }^{10,15}\right]$. Thus the absorption band at $4.5 \mathrm{eV}$ corresponds to $\left(\mathrm{Br}_{3}\right)_{a c a}$ centers and at $4.2 \mathrm{eV}$ (as with $\mathrm{KBr}\left[{ }^{5}\right]$ and $\mathrm{KCl}\left[{ }^{7}\right]$ ), to $\left(\mathrm{Br}_{3}^{-}\right)_{a c a} \mathrm{Rb}_{i}^{+} \mathrm{Br}_{\bar{i}}^{-}$centers.

A theory of linear $\mathrm{Br}_{3}^{-}$molecules is considered in $\left[{ }^{16,17}\right]$. The absorption at $4.5 \mathrm{eV}$ corresponds to ${ }^{1} \boldsymbol{\Sigma}_{g} \rightarrow{ }^{1} \boldsymbol{\Sigma}_{u}$ transition into the excited state with a repulsive potential, which leads to the photodissociation of $\mathrm{Br}_{3}$ centers with the creation of halogen atoms $\mathrm{Br}^{0}$ (i. e. $H$ centers). The creation of $H$ centers in $\mathrm{KBr}$ and $\mathrm{KCl}$ due to the photodissociation of $\mathrm{Br}_{3}^{-}$and $\mathrm{Cl}_{3}^{-}$centers is mentioned in $\left[{ }^{4,5}\right]$.

The weak TSL peaks at 43,49, and $52 \mathrm{~K}$ (Fig. 5,a) for the $\mathrm{RbBr}$ crystals $X$-rayed at $4.2 \mathrm{~K}$ correspond to the annealing of $H$ centers [9]. At $80 \mathrm{~K}$ and especially at $190 \mathrm{~K} H$ centers in $\mathrm{RbBr}$ crystals migrate to large distances and interact easily with $F$ centers and other defects of a crystal lattice.

Practically no absorption band appears at $4.8 \mathrm{eV}$ after an irradiation at $80 \mathrm{~K}$ when $v_{c}^{-}$in $\mathrm{RbBr}$ are immobile. The band is rather intensive in the crystals $X$-rayed at $190 \mathrm{~K}$ and especially at $300 \mathrm{~K}$. The number of the centers involved increases with heating crystals from 200 to $320 \mathrm{~K}$ when $v_{c}^{-}$and $v_{c}^{-} e^{+}$become mobile. A similar band at $5.8 \mathrm{eV}$ in $\mathrm{KCl}$ was interpreted as the absorption of $\left(\mathrm{Cl}_{2}{ }^{0}\right)_{2}$ associations $\left[{ }^{7}\right]$. According to $\left[{ }^{16}\right]$, this association should be regarded as a $T$-shaped $\mathrm{Cl}_{4}{ }^{0}$ molecule.

\section{Interstitial dipoles $\mathrm{Rb}_{i}+\mathrm{Br}_{i}^{-}$}

$I$ centers (single interstitial halogen ions $i_{a}^{-}$) are described in $\left[{ }^{8}\right]$ for $\mathrm{RbBr}$ crystals $X$-rayed at $16 \mathrm{~K}$. The TSL curve of $\mathrm{RbBr}$ crystal $X$-rayed at $4.2 \mathrm{~K}$, is shown in Fig. 5 , a. The main peak at $37 \mathrm{~K}$ corresponds to bimolecular annealing of single $I$ centers whose recombination with $F$ centers leads to the creation of conduction electrons $\left[{ }^{9}\right]$. The recombi- 
nation of electrons with $V_{K}$ centers causes the luminescence of selftrapped excitons (both $\pi$ emission with a maximum at $2.11 \mathrm{eV}$ and $\sigma$ emission at $4.15 \mathrm{eV})$. TSL peaks at 11,18 , and $27 \mathrm{~K}$ correspond to $\alpha, I$ correlation pairs.

More stable $I_{A}$ centers annealed at $T<250 \mathrm{~K}$ simultaneously with $\alpha$ centers (absorption of a halogen near $v_{a}^{+}$), are observed in $\mathrm{KBr}-\mathrm{Na}$ and $\mathrm{KBr}-\mathrm{Li}$ crystals $\left[{ }^{18}\right]$.

It follows from Fig. 2 that if heated up to $240 \mathrm{~K}$, the annealing of both low-temperature $I$ centers and $\alpha$ centers in $\mathrm{RbBr}$ is simultaneous. This part of $I$ centers is probably localized near $\mathrm{Na}^{+}$and $\mathrm{K}^{+}$ ions. However, the absorption band at $5.4 \mathrm{eV}$ (typical of $I$ centers) remains even after the heating up to $300 \mathrm{~K}$. The annealing of this band occurs only in the region of 350 to $425 \mathrm{~K}$ (Fig. $5, c$, curve $2^{\prime}$ ). As in $\mathrm{KCl}$ crystals $\left[{ }^{7,19}\right]$, the high-temperature $I$ centers in $\mathrm{RbBr}$ (absorption band at $5.4 \mathrm{eV}$ ) can be connected with the creation of interstitial dipoles $\mathrm{Rb}_{i}+\mathrm{Br}_{i}^{-}$. In $\mathrm{KCl}$ the reorientation of such dipoles occurs at $160 \mathrm{~K}$, and the annealing at $T>400 \mathrm{~K}\left[{ }^{19}\right]$. In $\mathrm{RbBr}$ the annealing of the $5.4 \mathrm{eV}$ absorption band occurs in the temperature range of 350 to $425 \mathrm{~K}$, but the reorientation of dipoles has not been studied yet.

When irradiating $\mathrm{RbBr}$ at $80 \mathrm{~K}$, interstitial dipoles must appear (see below) near $\mathrm{Br}_{3}$ centers. Therefore at the photodissociation of $\mathrm{Br}_{3}^{-}$centers by $4.67 \mathrm{eV}$ photons, not only the destruction of $\mathrm{Br}_{3}^{-}$but also $\mathrm{Rb}_{i}+\mathrm{Br}_{i}{ }^{-}$centers is expected due to the recombination of $v_{c}$ and $i_{c}^{+}$. In fact, after the optical destruction of $\mathrm{Br}_{3}^{-}$centers created by $X$-irradiation at $80 \mathrm{~K}$, the proportional bleaching of the absorption band at $5.4 \mathrm{eV}$ (which we consider to be the absorption of interstitial dipoles) takes place as well.

In $\mathrm{RbBr}$ crystals $X$-rayed at $190 \mathrm{~K}$ the majority of interstitial dipoles appear far from $\mathrm{Br}_{3}^{-}$centers. In this case a small number of dipoles is destroyed by $4.67 \mathrm{eV}$ photons. Up to now we have not succeeded in the selective bleaching of the absorption band at $5.4 \mathrm{eV}$ or in studying optically-induced dichroism of dipoles in $\mathrm{RbBr} X$-rayed at $80 \mathrm{~K}$.

\section{Creation of cation defects by irradiation}

With the increase of the $X$-irradiation dose of $\mathrm{RbBr}$ crystal, the number of $V_{F}$ centers (TSL peak at $230 \mathrm{~K}$ ) increases, and the absorption bands at $4.2,4.5 \mathrm{eV}\left(\mathrm{Br}_{3}^{-}\right.$centers $)$and $5.4 \mathrm{eV}\left(\mathrm{Rb}_{i}+\mathrm{Br}_{i}-\right.$ centers $)$ grow linearly.

Characteristics of color centers in $\mathbf{R b B r}$

\begin{tabular}{|c|c|c|c|}
\hline $\begin{array}{l}\text { Absorption } \\
\text { band, eV }\end{array}$ & $\begin{array}{c}\text { Decay } \\
\text { temperature, } \\
\mathrm{K}\end{array}$ & Symbol & Model \\
\hline $\begin{array}{c}6.31 \\
6.02 \\
5.45 ; 5.20 \\
5.4 \\
4.8 \\
4.5 \\
4.2 \\
1.81 \\
3.22 \\
3.3 \\
3.25\end{array}$ & $\begin{array}{l}\overline{-} \\
37 \\
400 \\
\overline{-} \\
380 \\
\overline{-} \\
190 \\
230 \\
52\end{array}$ & $\begin{array}{l}\beta \\
\alpha \\
I \\
- \\
\mathrm{Br}_{4}{ }^{0} \\
\mathrm{Br}_{3}^{-} \\
\mathrm{Br}_{3}^{-} \\
F \\
V_{K} \\
V_{F} \\
H\end{array}$ & 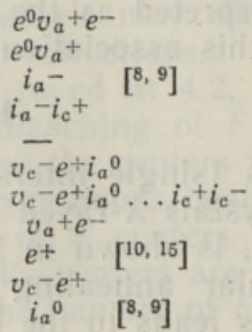 \\
\hline
\end{tabular}


In the region of 320 to $450 \mathrm{~K}$ the ionic conductivity of $\mathrm{RbBr} X$-rayed at $190 \mathrm{~K}$ grows as well. These facts testify to the creation of cation Frenkel defects by $X$-irradiation.

In Table the positions of the absorption bands, decay temperatures, conventional designations, and models of the investigated color centers in $\mathrm{RbBr}$, are compiled.

Five basic mechanisms of $v_{\mathrm{c}}^{-}$and $i_{\mathrm{c}}^{+}$creation in alkali halides are proposed:

1. At double ionization of a halogen ion a non-stable association of seven positively charged ions arises in the crystal, the decay of which may cause the creation of cation defects $\left[{ }^{20}\right]$.

2. Cation defects arise due to the decay of cation excitons which can be formed in $\mathrm{RbBr}$ by $16-17 \mathrm{eV}$ photons.

3. Cation defects in $\mathrm{RbBr}$ may be generated by the decay of self-trapped anion excitons formed by $6.5-7.0 \mathrm{eV}$ photons $\left[{ }^{3}\right]$.

4. The association of two $H$ centers may create a complex defect $v_{c}-e^{+} i_{a}{ }^{0} \ldots i_{c}+i_{a}-\left[{ }^{21}\right]$.

5. According to $\left[{ }^{22}\right]$, the interaction of $H$ and $V_{K}$ centers creates $v_{c}-e^{+} i_{a}{ }^{0} \ldots i_{c}+$ centers.

In order to elucidate the basic creation mechanisms of cation defects in $\mathrm{RbBr}$, we investigated the radiation defects produced by the $6.5-7.0 \mathrm{eV}$ photons using the TSL method. These photons create selectively anion excitons, but they cannot cause double ionization of halogen ions, cation excitons or a large number of holes. At such an excitation, some of the mechanisms mentioned above are impossible $(1,2)$ or improbable $(5)$.

At $190 \mathrm{~K}$ a $\mathrm{RbBr}$ crystal was irradiated by $6.7 \mathrm{eV}$ photons $\left(N=10^{8}\right.$ photons $/ \mathrm{cm}^{2} . \mathrm{s}$ ) which were distinguished from $\mathrm{CO}_{2}$-discharge by a VMR-2 vacuum monochromator. The curves of integral TSL measured after the irradiation with the heating rate of $0.3 \mathrm{~K} / \mathrm{s}$, are shown in Fig. 5, d. After 1 h irradiation (about $10^{17}$ excitons $/ \mathrm{cm}^{3}$ were obtained), $V_{F}$ centers (peak at $240 \mathrm{~K}$ ) and the centers responsible for TSL peak at $430 \mathrm{~K}$ arose. After an irradiation with a 130 times greater dose, in addition to $V_{F}$ peak a TSL peak at $370-380 \mathrm{~K}$ which corresponds (as was pointed above) to $\left(\mathrm{Br}_{3}^{-}\right)_{\text {aca }}$ centers, was distinctly observed. Thus, at a small dose anion excitons create $V_{F}$ centers in $\mathrm{RbBr}$, at a large irradiation dose, however, both $V_{F}$ and $\left(\mathrm{Br}_{3}{ }^{-}\right)$aca centers are created, which agrees well with mechanism 3 .

The author would like to express his gratitude to Ch. Lushchik, L. Pung, N. Lushchik for fruitful discussions, and to L. Ploom for supplying the crystals.

\section{REFERENCES}

1. I to h, N., Cryst. Lattice Defects, 3, № 3, 115-143 (1972).

2. Лущик Ч. Б., Витол И. К., Эланго М. А., Успехи физ. наук, 122, вып. 2, 223-251 (1977).

3. Витол И. К., Лущик Ч. Б., Эланго М. А., Физ. твердого тела, 10, вып. 9, $2753-2759$ (1968).

4. Лущик Ч. Б., Гинднна Р. И., Иыги Х. В., Плоом Л. А., Пунг Л. А., Тийслер Э. С., Эланго А. А., Яансон Н. А., Тр. ИФ АН ЭССР, № 43, 7-62 (1975).

5. Elango, A. A., Nurakhmetov, T. N., Phys. status solidi (b), 78, № 2, 529-536 (1976).

6. Пунг Л. А., Лущик А. Ч., Х алдре Ю. Ю., Изв. АН СССР, Сер. физ,, 40, № 9, $1952-1954$ (1976).

7. Лущик Ч. Б., Гиндина Р. И., Ма ароос А. А., Плоом Л. А., Лущик А. Ч., 
Пунг Л. А., Пыллуса ар Ю. В., Соовик Х. А., Физ. твердого тела, 19, вып. 12, 3625-3630 (1977).

8. S a idoh, M., It o h, N., Phys. status solidi (b), 72, № 2, 709-717 (1975).

9. Aboltin, D. E., Grabovskis, V. J., Kangro, A. R., Lushchik, Ch. B., O'K onnel-Bronin, A. A., Vitol, I. K., Z ir a p, V. E., Phys. status solidi (a), 47, № 2, 667-675 (1978).

10. Shoem aker, D., Phys. Rev., B7, № 2, 786-801 (1973).

11. Гиндина Р. И., Ма ароос А. А., Плоом Л. А., Пыллуса ар Ю. В., Ж. прикладной спектроскопии, 27, 스 3, 520-527 (1977).

12. Феоф илов П. П., К а плянский А. А., Успехи физ. наук, 76, вып. 2, 201-238 (1962)

13. King s le y, J. D., J. Phys. Chem. Solids, 23, № 7, 949-953 (1962).

14. Winter, E. M., Wolfe, D. R., Christy, R. W., Phys. Rev., 186, № 3, 949952 (1969).

15. Пунг Л. А., Х алдре Ю. Ю., Изв. АН СССР, Сер. физ., 30, № 9, 1446-1447 (1966).

16. Pimentel, G. C., Chemical Bonding Clarified through Quantum Mechanics, Holden-Day, Amsterdam, 1970.

17. T a sker, P. W., Mol. Phys. 33, № 2, 511-518 (1977).

18. Gi uli a n i, G., Phys. Rev., B2, № 2, 464-471 (1970).

19. S tot t, J. P., C r a w f o r d, J. H., Phys. Rev., B6, № 12, 4660-4667 (1972).

20. V a r le y, J. H. O., J. Nucl. Energy, 1, № 1, 130-143 (1954).

21. Cat $10 \mathrm{w}$, C. R. A., Diller, K. M., Norgett, M. J., J. Phys. C: Solid State Phys., 8, № 3, L34-L36 (1975).

22. Lushchik, Ch. B., Elango, A. A., Gindina, R. I., Lushchik, A. Ch., M a roos, A. A., Nurakhmetov, T. N., Pung, L. A., Pōllus a a r, Yu. V., S oovik, H. A., J a a n S o n, N. A., Intern. Conf. on Defects in Insulating Crystals (Abstr.), Gatlinburg, USA, 1977, p. 273-274.

Tartu State University

Received

Nov. 19,1979

\section{A. LUSTSIK}

\section{KIIRITATUD RbBr KRISTALLIDE KATIOONSETE DEFEKTIDE OPTILINE UURIMINE}

RbBr kristallide kiiritamisel temperatuuril 80 ja $190 \mathrm{~K}$ tekivad kaht tüüpi $\mathrm{Br}_{3}{ }^{-}$-tsentrid, mis on orienteerunud suundades $\langle 100\rangle$ ja neelavad piirkonnas 4,5 või $4,2 \mathrm{eV}$. Nende tsentrite fotodissotsieerumisel tekivad $V_{F}$-tsentrid (katioonvakantsi juures lokaliseeruv auk). Röntgenkiiritus tekitab veel neeldumisriba $5,4 \mathrm{eV}$, mis on stabililne kuni temperatuurini $425 \mathrm{~K}$ ja mida võib tẽlgendada kui sõlmedevahelise $\mathrm{Rb}_{i}+\mathrm{Br}_{i}-$ dipooli neelamist. On käsitletud katioonsete Frenkeli defektide tekkimise vőimalikke mehhanisme.

\section{А. ЛУЩИК}

\section{ОПТИЧЕСКОЕ ИССЛЕДОВАНИЕ КАТИОННЫХ ДЕФЕКТОВ В ОБЛУЧЕННЫХ КРИСТАЛЛАХ $\mathrm{RbBr}$}

В случае облучения кристаллов $\mathrm{RbBr}$ при 80 и $190 \mathrm{~K}$ создаются $\mathrm{Br}_{3}^{-}$-центры двух типов, ориентированные по направлениям $<100\rangle$ и поглощающие в области 4,5 и 4,2 эB. При фотодиссоциации этих центров создаются $V_{\boldsymbol{F}}$-центры (дырка, локализованная около катионной вакансии). Облучение рентгеновскими лучами приводит, кроме того, к появлению стабильной до $425 \mathrm{~K}$ полосы поглощения 5,4 эB, которая может быть интерпретирована как поглощение междоузельных диполей $\mathrm{Rb}_{i}+\mathrm{Br}_{i}-$. Обсуждаются возможные механизмы создания катионных френкелевских дефектов. 